Article

\title{
Suppression of Wnt Signaling and Osteogenic Changes in Vascular Smooth Muscle Cells by Eicosapentaenoic Acid
}

\author{
Yukihiro Saito ${ }^{1, *}$, Kazufumi Nakamura ${ }^{1, *}$, Daiji Miura ${ }^{1,2}$, Kei Yunoki ${ }^{1}$, Toru Miyoshi ${ }^{1}$, \\ Masashi Yoshida 1,3, Norifumi Kawakita ${ }^{1}$, Tomonari Kimura ${ }^{1}$, Megumi Kondo ${ }^{1}$, \\ Toshihiro Sarashina ${ }^{1}$, Satoshi Akagi ${ }^{1}$, Atsuyuki Watanabe ${ }^{1}$, Nobuhiro Nishii ${ }^{1,4}$, \\ Hiroshi Morita ${ }^{1,4}$ and Hiroshi Ito ${ }^{1}$ \\ 1 Department of Cardiovascular Medicine, Okayama University Graduate School of Medicine, Dentistry, \\ and Pharmaceutical Sciences, Okayama 700-8558, Japan; miura-daiji@nagano-nurs.ac.jp (D.M.); \\ yunokei@yahoo.co.jp (K.Y.); miyoshit@cc.okayama-u.ac.jp (T.M.); masashiyoshid@gmail.com (M.Y.); \\ rm3ta6@bma.biglobe.ne.jp (N.K.); tomonari_ver21@yahoo.co.jp (T.K.); \\ bethnyan.fujituki.sibowchan@gmail.com (M.K.); sarashina.toshihiro@gmail.com (T.S.); \\ akagi-s@cc.okayama-u.ac.jp (S.A.); waatsu2034@yahoo.co.jp (A.W.); nnnnishii2001@gmail.com (N.N.); \\ hmorita@cc.okayama-u.ac.jp (H.M.); itomd@md.okayama-u.ac.jp (H.I.) \\ 2 Department of Basic Medicine, Nagano College of Nursing, Komagane 399-4117, Japan \\ 3 Department of Chronic Kidney Disease and Cardiovascular Disease, Okayama University Graduate School \\ of Medicine, Dentistry and Pharmaceutical Sciences, Okayama 700-8558, Japan \\ 4 Department of Cardiovascular Therapeutics, Okayama University Graduate School of Medicine, Dentistry, \\ and Pharmaceutical Sciences, Okayama 700-8558, Japan \\ * Correspondence: saitou-y@cc.okayama-u.ac.jp (Y.S.); ichibun@cc.okayama-u.ac.jp (K.N.); \\ Tel./Fax: +81-86-235-7351 (Y.S. \& K.N.)
}

Received: 11 July 2017; Accepted: 7 August 2017; Published: 10 August 2017

\begin{abstract}
Vascular medial calcification is often observed in patients with arteriosclerosis. It is also associated with systolic hypertension, wide pulse pressure, and fluctuation of blood pressure, which results in cardiovascular events. Eicosapentaenoic acid (EPA) has been shown to suppress vascular calcification in previous animal experiments. We investigated the inhibitory effects of EPA on Wnt signaling, which is one of the important signaling pathways involved in vascular calcification. Intake of food containing 5\% EPA resulted in upregulation of the mRNA expression of Klotho, an intrinsic inhibitor of Wnt signaling, in the kidneys of wild-type mice. Expression levels of $\beta$-catenin, an intracellular signal transducer in the Wnt signaling pathway, were increased in the aortas of Klotho mutant $(\mathrm{kl} / \mathrm{kl})$ mice compared to the levels in the aortas of wild-type mice. Wnt3a or BIO, a GSK-3 inhibitor that activates $\beta$-catenin signaling, upregulated mRNA levels of AXIN2 and LEF1, Wnt signaling marker genes, and RUNX2 and BMP4, early osteogenic genes, in human aorta smooth muscle cells. EPA suppressed the upregulation of AXIN2 and BMP4. The effect of EPA was cancelled by T0070907, a PPAR $\gamma$ inhibitor. The results suggested that EPA could suppress vascular calcification via the inhibition of Wnt signaling in osteogenic vascular smooth muscle cells via PPAR $\gamma$ activation.
\end{abstract}

Keywords: vascular calcification; eicosapentaenoic acid; Wnt signaling

\section{Introduction}

Vascular calcification is observed in arteriosclerosis and reduces aortic and arterial elastance. Intimal calcification is commonly associated with atherosclerosis. Medial calcification is often observed in patients with type 2 diabetes mellitus and end-stage renal disease, and is known as Mönckeberg's 
medial sclerosis (MMS). This type of calcification leads to systolic hypertension and fluctuation of blood pressure, finally causing cardiac hypertrophy, myocardial ischemia, peripheral arterial ischemia, and congestive heart failure [1-5].

Eicosapentaenoic acid (EPA) is effective for the prevention and treatment of arteriosclerotic diseases [6-9]. EPA has also suppressed vascular calcification in animal experiments [10-14]. Since EPA has multiple physiological activities, it is important to clarify the specific mechanism by which vascular calcification is suppressed.

The Wnt signaling pathway is involved in various aging phenotypes, including vascular calcification [15-22]. Patients with chronic kidney disease (CKD) show significant arterial calcification, and have a very high risk of developing cardiovascular diseases $[23,24]$. They also have mineral and bone disorders, and high phosphate induces vascular calcification through activating Wnt/ $\beta$-catenin signaling [25]. Klotho mutant $(k l / k l)$ mice show severe tissue calcium deposition, including vascular medial calcification [21]. Since Klotho binds to multiple Wnt ligands and inhibits Wnt signaling activation, Wnt signaling is activated in $\mathrm{kl} / \mathrm{kl}$ mice [22,26]. Klotho is mainly produced in the kidneys, and the secreted form is released into the blood $[27,28]$. Reduced production of klo tho is also observed in Patients with CKD [25].

Since we have observed a remarkable suppressive effect of EPA on arterial calcification of $k l / k l$ mice [12], we investigated the effect of EPA on Wnt signaling in arterial calcification. We first examined whether EPA can upregulate Klotho expression in the kidney. Meanwhile, the intake of powder chow supplemented with 5\% purified EPA significantly suppressed vascular calcification in $\mathrm{kl} / \mathrm{kl}$ mice, despite a defect of Klotho production [12]. Additionally, whether Klotho is expressed in the artery is controversial [29-31]. Thus, we consequently investigated the effects of EPA on Wnt signaling in vascular smooth muscle cells (VSMCs).

\section{Materials and Methods}

\subsection{Animal Experiment}

Klotho mutant $(k l / k l)$ mice were purchased from Clea Japan (Tokyo, Japan). Four-week-old $k l / k l$ mice and wild-type mice were given diets either containing 5\% EPA (Mochida Pharmaceutical Co., Ltd., Tokyo, Japan) (EPA diet), or not containing EPA (control diet), for four weeks. All animal protocols were approved and conducted according to the recommendations of Okayama University on Animal Care and Use. The animal procedures performed conform to the National Institutes of Health (NIH) guidelines (Guide for the Care and Use of Laboratory Animals).

\subsection{Immunohistochemical Staining}

Mice were anesthetized by intraperitoneal injection of $40 \mathrm{mg} / \mathrm{kg}$ pentobarbital (Kyoritsu Seiyaku Corporation, Tokyo, Japan). Then, thoracotomy was performed, and the mice were transcardially perfused with saline. The aorta and kidney of each mouse were harvested under a stereoscopic microscope (SZ61, Olympus, Tokyo, Japan). The aorta was embedded in Optimal Cutting Temperature Compound (Sakura Fintek, Tokyo, Japan). The embedded tissues were sectioned at $5 \mu \mathrm{m}$ in a microtome (CM1850, Leica, Wetzlar, Germany) and mounted on slide glasses (S-0317, Matsunami Glass, Osaka, Japan). They were fixed in 4\% paraformaldehyde for $15 \mathrm{~min}$, followed by incubation with Blocking One Histo (Nacalai Tesque, Kyoto, Japan) for $30 \mathrm{~min}$, and then they were stained with primary antibodies against $\beta$-catenin (1:100 dilution, D10A8 XP, Cell Signaling Technology, Danvers, MA, USA) and $\alpha$-SMA (1:400 dilution, Clone 1A4, Sigma Aldrich, St. Louis, MO, USA). The secondary antibodies used were tetramethylrhodamine (TRITC) swine anti-rabbit Ig (1:20, Dako, Santa Clara, CA, USA), and Alexa Fluor 488 goat anti-mouse IgG (1:200, Molecular Probes, Eugene, OR, USA).

\subsection{Cell Culture}

Primary human aortic smooth muscle cells (HAoSMCs) purchased from Lonza (Basel, Switzerland) were cultured in Smooth Muscle Growth Medium-2 (SmGM-2, Lonza). Cells between passages 5-9 
were used for all experiments. In loading experiments, cells were cultured in Dulbecco's Modified Eagle Medium (DMEM) (Invitrogen, Carlsbad, CA, USA) supplemented with 0.5\% fetal bovine serum (HyClone, South Logan, UT, USA), and some reagents and were harvested after 48 h. EPA (Sigma Aldrich) was dissolved in ethanol. One hundred ng/mL Wnt3a (R\&D Systems, Minneapolis, MN, USA), $1 \mu \mathrm{g} / \mathrm{mL}$ heparin (Sigma Aldrich), $1 \mu \mathrm{mol} / \mathrm{L}$ 6-bromoindirubin-3'-oxime (BIO) (Wako, Osaka, Japan), and/or $10 \mu \mathrm{mol} / \mathrm{L}$ T0070907 (Tocris Bioscience, Bristol, UK) were used in cell culture experiments.

\subsection{Cell Staining}

HAoSMCs were plated on $0.1 \%$ gelatin-coated cover glasses, and fixed in $4 \%$ paraformaldehyde. The cells were stained with rhodamine-phalloidin (1:200 dilution, Molecular Probes, Eugene, OR, USA) and Hoechst 33342 (1:5000 dilution, Molecular Probes). Rhodamine-phalloidin is an F-actin probe conjugated to the red-orange fluorescent dye, tetramethylrhodamine. Hoechst 33342 is a blue dye for cell fluorescence of nuclei.

\subsection{Quantitative PCR}

Murine kidneys in Trizol Reagent were homogenized using Bead Crusher $\mu$ T-01 (Taitec, Saitama, Japan). HAoSMCs were also lysed using Trizol Reagent. Total RNA was extracted using a Trizol Plus RNA Purification Kit (Invitrogen, Carlsbad, CA, USA). Complementary DNA was synthesized from less than $1 \mu \mathrm{g}$ of total RNA using a SuperScript VILO cDNA Synthesis Kit (Invitrogen), as prescribed in the manual and subjected to PCR amplification. Taq DNA polymerase (Takara, Shiga, Japan) was used for reverse transcription-polymerase chain reaction (RT-PCR), and PCR products were subjected to electrophoresis in $2 \%$ agarose gels and stained with ethidium bromide. KAPA SYBR Fast qPCR Kit (Kapa Biosystems, Wilmington, MA, USA) and Applied Biosystems 7300 Real-Time PCR Systems (Applied Biosystems, Foster City, CA, USA) were used for quantitative PCR ( $q$-PCR). The $q$-PCR data were processed by a $\triangle \triangle \mathrm{CT}$ method. PCR primers are shown in Table 1 . The $q$-PCR experiments were performed in triplicate four times.

Table 1. PCR primer pairs.

\begin{tabular}{|c|c|c|c|c|}
\hline & & Sequence & Annealing Temperature $\left({ }^{\circ} \mathrm{C}\right)$ & Product Size $(\mathrm{bp})$ \\
\hline \multicolumn{5}{|l|}{ Mouse } \\
\hline \multirow{2}{*}{ Klotho } & forward & CAAAGTCTTCGGCCTTGTTC & \multirow[b]{2}{*}{60} & \multirow{2}{*}{111} \\
\hline & reverse & CTCССCAAGCAAAGTCACA & & \\
\hline \multirow{2}{*}{ Pparg } & forward & ATCATCTACACGATGCTGGCC & \multirow{2}{*}{60} & \multirow{2}{*}{81} \\
\hline & reverse & CTCCCTGGTCATGAATCCTTG & & \\
\hline \multirow[b]{2}{*}{ Ffar4 } & forward & TGCCCCTCTGCATCTTGTTC & \multirow[b]{2}{*}{60} & \multirow[b]{2}{*}{202} \\
\hline & reverse & CGCGATGCTTTCGTGATCTG & & \\
\hline \multirow{2}{*}{$A c t b$} & forward & GGAGGGGGTTGAGGTGTT & \multirow[b]{2}{*}{60} & \multirow[b]{2}{*}{70} \\
\hline & reverse & GTGTGCACTTTTATTGGTCTCAA & & \\
\hline \multicolumn{5}{|l|}{ Human } \\
\hline \multirow{2}{*}{ AXIN2 } & forward & AGTGTGAGGTCCACGGAAAC & \multirow[b]{2}{*}{58} & \multirow[b]{2}{*}{103} \\
\hline & reverse & CTGGTGCAAAGACATAGCCA & & \\
\hline \multirow{2}{*}{$L E F 1$} & forward & AATGAGAGCGAATGTCGTTGC & \multirow[b]{2}{*}{60} & \multirow{2}{*}{137} \\
\hline & reverse & GCTGTCTTTCTTTCCGTGCTA & & \\
\hline \multirow{2}{*}{ RUNX2 } & forward & TCTTAGAACAAATTCTGCCCTTT & \multirow[b]{2}{*}{58} & \multirow{2}{*}{136} \\
\hline & reverse & TGCTTTGGTCTTGAAATCACA & & \\
\hline \multirow{2}{*}{$B M P 4$} & forward & GATCCACAGCACTGGTCTTG & \multirow[b]{2}{*}{60} & \multirow{2}{*}{150} \\
\hline & reverse & GGGATGCTGCTGAGGTTAAA & & \\
\hline \multirow{2}{*}{ PPARG } & forward & GGCTTCATGACAAGGGAGTTTC & \multirow[b]{2}{*}{60} & \multirow{2}{*}{74} \\
\hline & reverse & AACTCAAACTTGGGCTCCATAAAG & & \\
\hline \multirow{2}{*}{ MYH11 } & forward & AGATGGTTCTGAGGAGGAAACG & \multirow{2}{*}{60} & \multirow{2}{*}{85} \\
\hline & reverse & AAAACTGTAGAAAGTTGCTTATTCACT & & \\
\hline \multirow{2}{*}{ FFAR4 } & forward & CTGTGCAGGAATGAGTGGAAG & 60 & 197 \\
\hline & reverse & CTGATGGAGGGTACTGGAAATG & 60 & 197 \\
\hline & forward & GCGAGATCCСТCCAAAATCAA & & \\
\hline GAPDH & reverse & GTTCACACCCATGACGAACAT & 58 & 172 \\
\hline
\end{tabular}




\subsection{FFAR4 Knockdown by siRNA}

To knockdown FFAR4 in HAoSMCs, 5 m mol/L small interfering RNA (siRNA, s200889, Ambion, Foster City, CA, USA) was transfected using Lipofectamine RNAiMAX (Invitrogen) according to the manufacturer's instructions. FFAR4 downregulation was confirmed by RT-PCR.

\subsection{Statistical Analysis}

All data are expressed as means \pm SE. Statistical analysis was performed by Student's $t$ test for unpaired data or one-way ANOVA, with comparison of different groups by Tukey's post hoc test using SPSS statistics 24 (IBM, Armonk, NY, USA). Values of $p<0.05$ were considered to be significant.

\section{Results}

\subsection{Intake of EPA Food Upregulated Klotho Expression in Kidneys of Wild-Type Mice}

Klotho mRNA levels in mice fed the EPA diet $(n=8)$ were about 1.5 times higher than the levels in mice fed the control diet $(n=4)$ (Figure 1A). In $k l / k l$ mice, the intake of EPA did not change serum phosphate, and did not increase Klotho expression (control diet, $n=2$; EPA diet, $n=2$ ) (Figure 1B) [12]. Expression of the nuclear receptor and plasma membrane receptor of EPA, PPAR $\gamma$ and FFAR4, respectively, were confirmed by RT-PCR (Figure 1C).
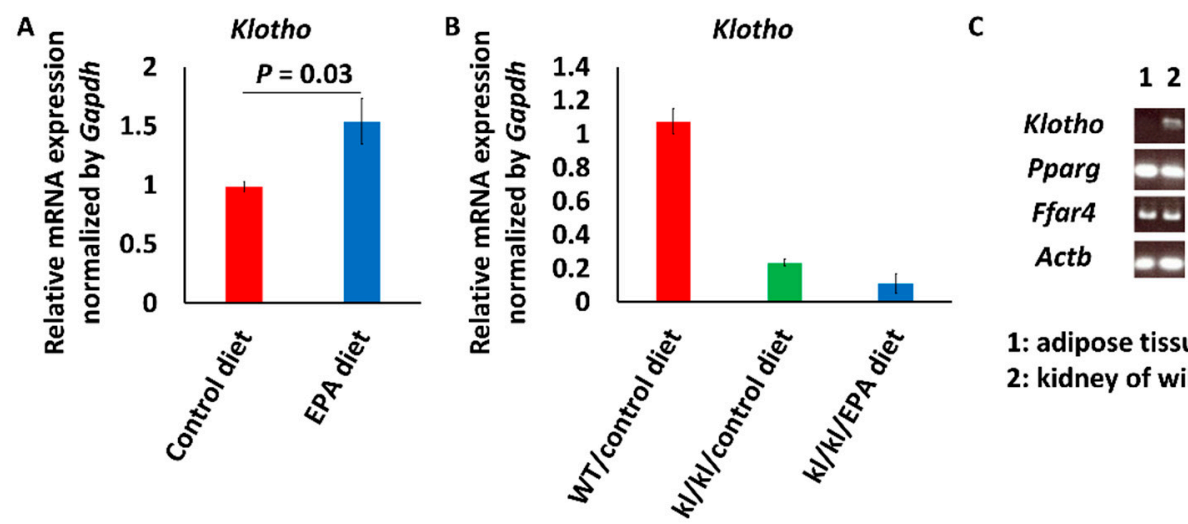

1: adipose tissue of wild-type mouse 2: kidney of wild-type mouse

Figure 1. Klotho $(k l / k l)$ mRNA expression levels in kidneys of mice. (A) Klotho mRNA expression levels in kidneys of wild-type mice fed a diet with or without eicosapentaenoic acid (EPA). Data are shown as means \pm SE (Control diet, $n=4$; EPA diet, $n=8$ ) and were analyzed using Student's $t$ test; (B) Klotho mRNA expression levels in kidneys of $k l / k l$ mice fed a diet with or without EPA. Data are shown as means ( $n=2$ in each group); (C) Reverse transcription-polymerase chain reaction (RT-PCR) showed the mRNA of EPA receptors, Pparg and Ffar4, in the kidney.

\subsection{Beta-Catenin Expression Increased in the Aortas of $\mathrm{Kl} / \mathrm{kl}$ Mice}

The medial layer, which was $\alpha$-SMA positive, showed hyperplasia, while the expression of $\beta$-catenin, an intracellular signal transducer in the Wnt signaling pathway, was detected in more sections of aortas from $\mathrm{kl} / \mathrm{kl}$ mice (control diet, number of animals $=2$ and number of tissue sections $=7$; EPA diet, number of animals $=2$ and number of tissue sections $=6$ ) than in sections of aortas from wild-type mice (control diet, number of animals $=2$ and number of tissue sections $=6$; EPA diet, number of animals $=2$ and number of tissue sections $=7$ ) (Figure 2A,B).

\subsection{EPA Suppressed the Expression of Wnt Signaling Marker and Early Osteogenic Genes}

Wnt3a (100 ng/mL) increased not only the expression of Wnt signaling marker genes AXIN2 and LEF1, but also the expression of RUNX2 and BMP4, which are genes associated with vascular calcification [20,32-35]. Upregulation of these genes was suppressed by $25 \mu \mathrm{mol} / \mathrm{L}$ EPA (Figure 3A). 
EPA did not completely suppress the upregulation genes by Wnt3a at $10 \mu \mathrm{mol} / \mathrm{L}$, and $100 \mu \mathrm{mol} / \mathrm{L}$ EPA induced cell death (Figure 3B). We therefore used $25 \mu \mathrm{mol} / \mathrm{L} \mathrm{EPA} \mathrm{in} \mathrm{subsequent} \mathrm{experiments.}$

A

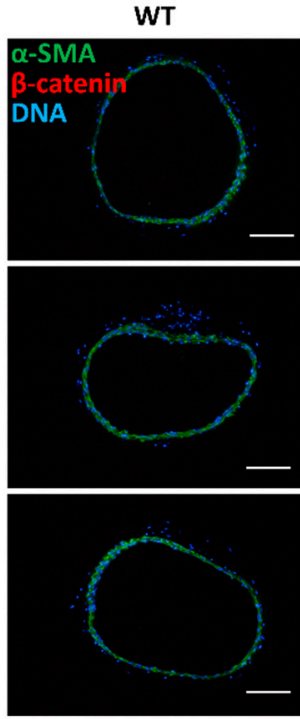

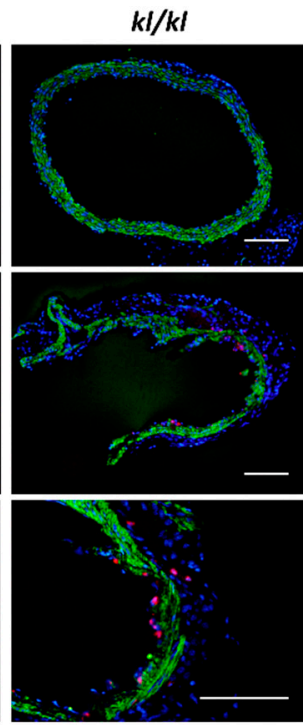

B

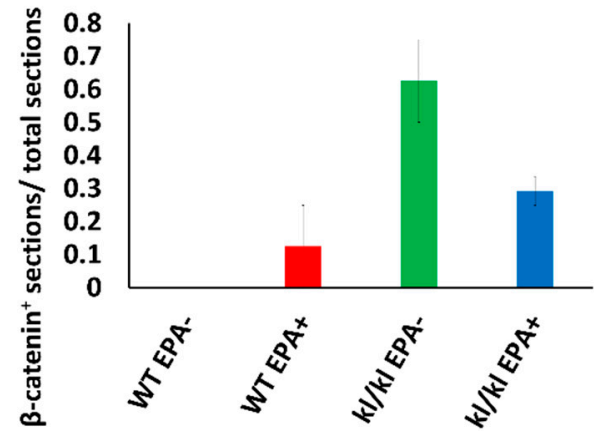

Figure 2. Beta-catenin expression in aortas of mice. (A) Immunostaining of mouse aortas: green, $\alpha$-smooth muscle actin ( $\alpha$-SMA); red, $\beta$-catenin; and blue, DNA; (B) Proportions of $\beta$-catenin-positive aorta sections (total numbers of sections: Wild-type (WT) mice fed control diet, $n=7$; WT mice fed EPA diet, $n=6 ; k l / k l$ mice fed control diet, $n=6$; and $k l / k l$ mice fed EPA diet, $n=7)$. Bar $=100 \mu \mathrm{m}$.

A
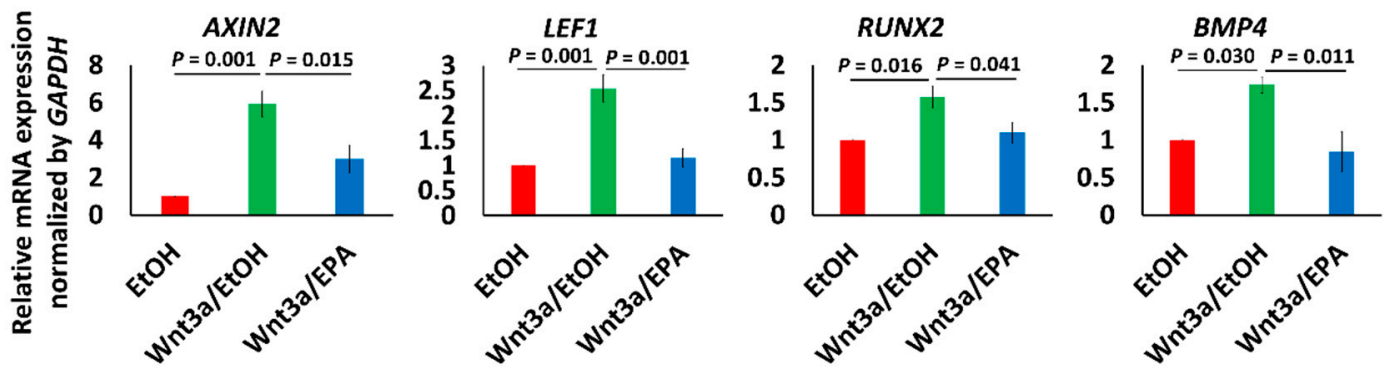

B
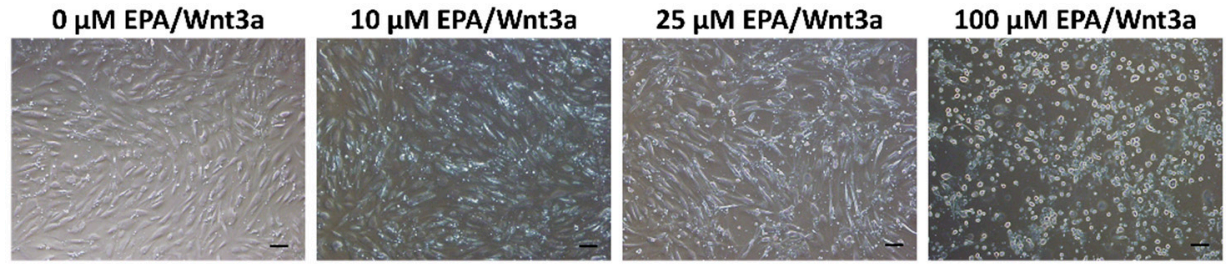

Figure 3. Effects of Wnt3a and EPA on human aortic smooth muscle cells (HAoSMCs). (A) Changes of the gene expression pattern in HAoSMCs treated with or not treated with $100 \mathrm{ng} / \mathrm{mL} \mathrm{Wnt3a}$ and/or EPA. Data are shown as means \pm SE ( $n=4$ in each group), and were analyzed using one-way ANOVA with Tukey's post hoc test. EtOH means ethanol; (B) Cytotoxicity of EPA in HAoSMCs. Bar $=100 \mu \mathrm{m}$.

\subsection{EPA Suppressed $\beta$-Catenin Signaling via PPAR $\gamma$ Activation}

$\mathrm{BIO}(1 \mu \mathrm{mol} / \mathrm{L})$, a GSK-3 inhibitor that activates $\beta$-catenin signaling, also increased the expression of AXIN2, LEF1, RUNX2 and BMP4. Upregulation of AXIN2 and BMP4 was significantly suppressed, and RUNX2 tended to be suppressed by $25 \mu \mathrm{mol} / \mathrm{L}$ EPA. EPA is known as a PPAR $\gamma$ agonist and also increased PPARG expression. The effects of EPA were cancelled by $10 \mu \mathrm{mol} / \mathrm{L}$ T0070907, a PPAR $\gamma$ inhibitor (Figure 4A). Additionally, BIO made actin fibers sparse, and EPA modestly mitigated the 
morphological change. The expression of $M Y H 11$, a mature contractile smooth muscle cell marker, was decreased by BIO, and the expression was recovered by EPA. T0070907 cancelled the effect of EPA (Figure 4A,B). The knockdown of FFAR4, a receptor of $\omega-3$ fatty acids, did not cancel the inhibitory effect of EPA on AXIN2 and LEF1 expression (Figure 5A,B) [36].
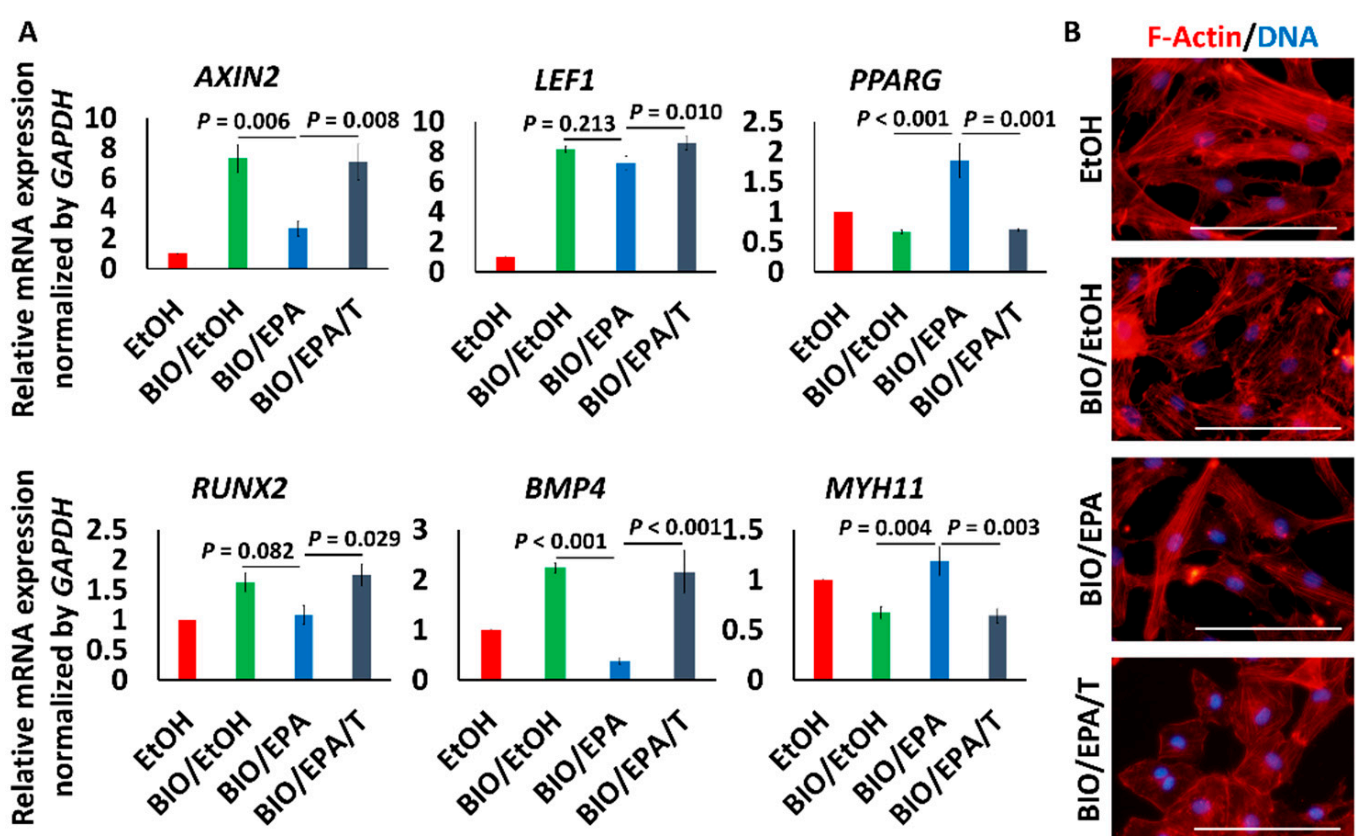

Figure 4. Effects of EPA on $\beta$-catenin signaling stimulated by GSK-3 inhibitor. (A) Changes of the gene expression pattern in HAoSMCs treated with $1 \mu \mathrm{mol} / \mathrm{L} \mathrm{BIO}$, with or without EPA/T0070907. Data are shown as means \pm SE ( $n=4$ in each group) and were analyzed using one-way ANOVA with Tukey's post hoc test. T means T0070907 (10 $\mu \mathrm{mol} / \mathrm{L})$; (B) Morphological changes of HAoSMCs. Red and blue represent $f$-actin and DNA, respectively. Bar $=100 \mu \mathrm{m}$.

A
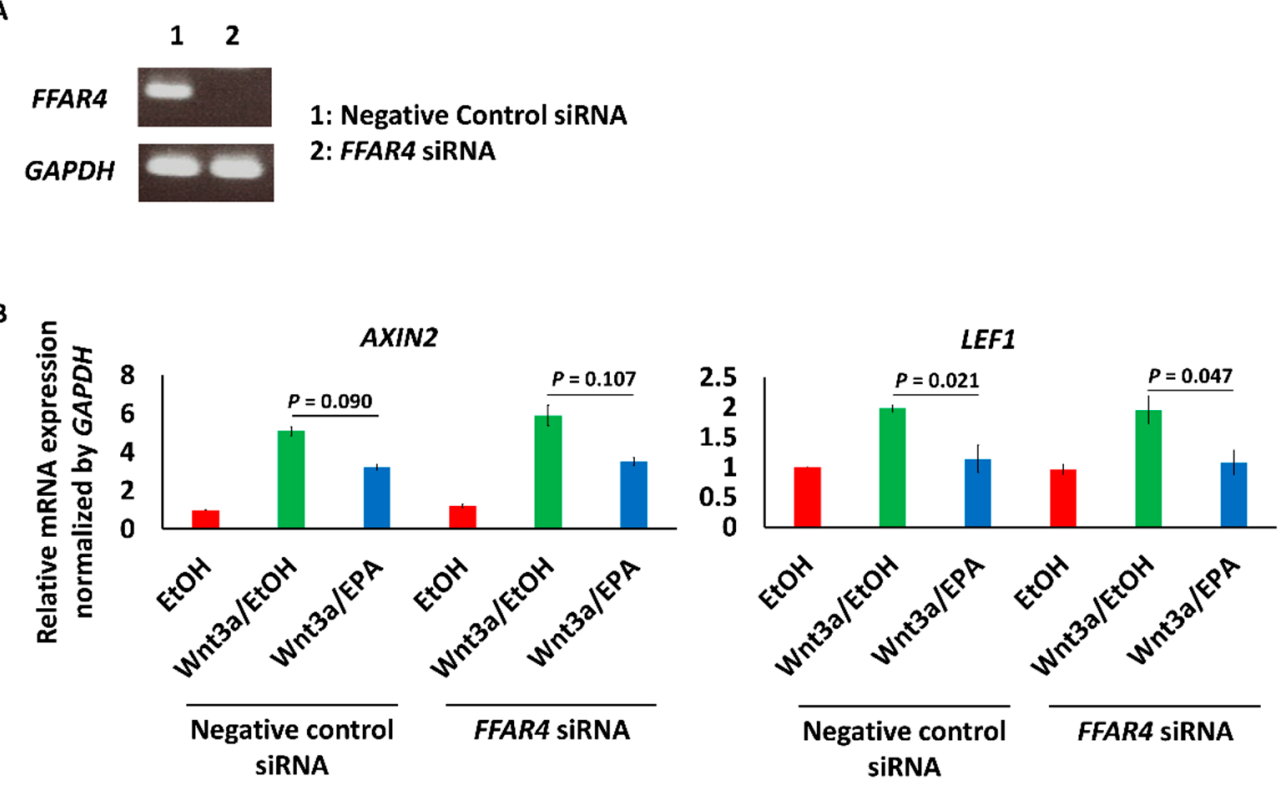

Figure 5. Effect of the knockdown of FFAR4 on Wnt signaling in HAoSMCs. (A) The knockdown of FFAR4 in HAoSMCs was confirmed by RT-PCR; (B) The effect of knockdown of FFAR4 on the expression of AXIN2 and LEF1, downstream genes of Wnt signaling. Data are shown as means $\pm \mathrm{SE}$ ( $n=3$ in each group) and were analyzed using one-way ANOVA with Tukey's post hoc test. 


\section{Discussion}

Our study revealed that EPA upregulated the expression of Klotho, a Wnt signaling inhibitor, in the kidney and inhibited Wnt signaling in osteogenic VSMCs via PPAR $\gamma$, as shown in Figure 6. These results suggested that the effects could lead to the suppression of vascular calcification. In addition to our previous study, the results of the present study using human VSMCs suggested that EPA can also affect human vascular calcification by the suppression of Wnt signaling [12]. This study is therefore a step toward the pathology of arteriosclerosis.

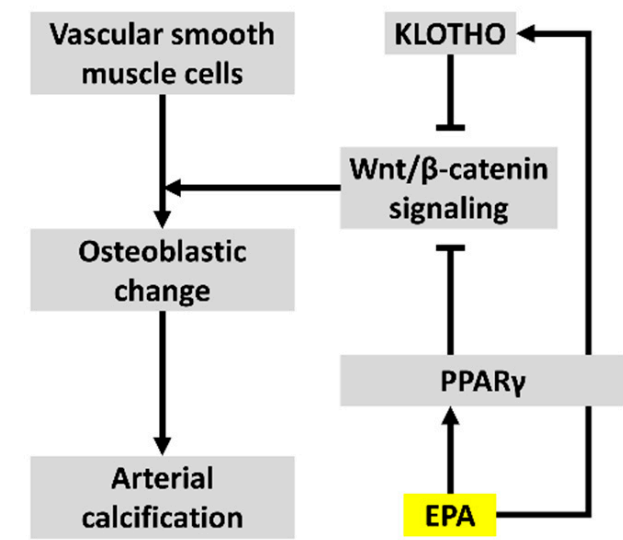

Figure 6. Mechanisms by which EPA suppresses vascular calcification via inhibition of Wnt signaling.

The intake of EPA increased Klotho mRNA expression in the kidney, as shown in Figure 1. Klotho inhibits the binding of Wnt ligands to their receptors [26]. The upregulated expression of Klotho in the kidney is presumed to suppress vascular calcification; however, we did not examine how EPA upregulated Klotho expression. Meanwhile, PPAR $\gamma$ activation has been reported to be one of the methods for increasing Klotho production in the kidney, because the Klotho gene has a PPAR-responsive element (PPRE) [25,37]. Additionally, EPA can directly activate PPAR $\gamma$ [38]. The upregulation of expression by EPA that was observed in our study is a compatible result. However, wild-type mice were used in this study to examine Klotho expression in the kidneys. Thus, it is unclear whether EPA increases Klotho production in a pathological situation. Further investigation using other pathological model animals without a Klotho defect is therefore required.

We previously reported that intake of an EPA diet also significantly suppressed vascular calcification in $\mathrm{kl} / \mathrm{kl}$ mice, despite a defect of Klotho production [12]. Furthermore, it is not clear whether vascular Klotho is expressed endogenously [29-31]. Thus, we consequently investigated the direct effects of EPA on Wnt signaling in the aorta. Increased $\beta$-catenin expression in the aortas of $k l / k l$ mice, as shown in Figure 2, suggested an enhancement of Wnt/ $\beta$-catenin signaling in the calcified aorta.

Vascular calcification in the tunica media observed in $k l / k l$ mice and CKD patients is a characteristic manifestation [21,39]. We therefore investigated the effect of EPA in VSMCs, which are a component of the tunica media. We revealed that the enhancement of $\mathrm{Wnt} / \beta$-catenin signaling by a Wnt ligand or a GSK-3 $\beta$ inhibitor resulted in osteogenic changes of human VSMCs, as previous studies have demonstrated [18-20,34,40]. Furthermore, EPA suppressed the changes, as shown in Figures 3 and 4. EPA has also been reported to prevent palmitic acid-induced osteoblastic changes in VSMCs [41]. The mechanisms by which EPA suppresses vascular calcification have been reported to be a reduction of matrix metalloproteinase production, and a reduction of oxidative stress [11,12]. It has been shown that $\omega-3$ fatty acids are known to suppress Wnt signaling in various types of cancer cells [42-44]. Thus, our results, shown in Figure 4, suggested that similar mechanisms might act in osteogenic VSMCs via activation of $\operatorname{PPAR} \gamma$. 
We previously reported that FFAR4 signaling is responsible for decreasing oxidative stress in mice [12]; however, FFAR4 was not associated with the inhibitory effects of EPA on Wnt signaling in this experimental situation, as shown in Figure 5. These results suggested that FFAR4 signaling might suppress vascular calcification by other mechanisms.

It is not known whether a decrease in coronary calcification reduces cardiovascular events. Vascular calcification seems to prevent the rupture of vulnerable plaques, because a statin could increase vascular calcification, despite the reduction of cardiovascular events [45,46]. Evaluation using optical coherence tomography and intravascular ultrasound demonstrated that adding on EPA to statin did not change calcified plaque volume; however, it did stabilize the plaques of human coronary arteries $[47,48]$. Our study revealed that EPA suppresses Wnt signaling in smooth muscle cells. EPA is also known to affect macrophages and endothelial cells [49-51]. Additionally, Wnt signaling is associated with inflammation and aging [52,53]. EPA therefore seems to affect not only vascular calcificationm but also other arteriosclerotic processes via the modulation of Wnt signaling [54].

Since the amount of intake of EPA in this study is extremely large for humans, we should look for a specific target for clinical implication. EPA is converted to metabolites with various physiological activities in vivo [55-58]. We did not examine metabolites in this study because it is difficult to understand the effects of metabolites produced by cells other than VSMCs, e.g., endothelial cells, in an in vitro study [59]. Thus, analyses of metabolites in each tissue or organ might be useful to gain a deeper understanding of the effects of EPA on vascular calcification.

In conclusion, this study revealed that EPA increased the expression of Klotho, an inhibitor of Wnt signaling, in the kidney, and inhibited osteogenic change via enhancement of Wnt signaling in VSMCs. These effects of EPA might lead to suppression of vascular calcification.

Acknowledgments: The authors are grateful to Kaoru Akazawa and Masayo Ohmori for their technical assistance.

Author Contributions: Y.S. and K.N. conceived the idea and designed the research; Y.S., D.M., K.Y., N.K., T.K., M.K., T.S. and S.A. performed the experiments; Y.S., M.Y. and T.M. analyzed data; K.N., A.W. and N.N. evaluated the results; Y.S. and K.N. wrote the paper; H.M. and H.I. are supervisors. All authors read and approved the final version of this manuscript.

Conflicts of Interest: The authors have no conflict of interest to declare.

\section{References}

1. Sangiorgi, G.; Rumberger, J.A.; Severson, A.; Edwards, W.D.; Gregoire, J.; Fitzpatrick, L.A.; Schwartz, R.S. Arterial calcification and not lumen stenosis is highly correlated with atherosclerotic plaque burden in humans: A histologic study of 723 coronary artery segments using nondecalcifying methodology. J. Am. Coll. Cardiol. 1998, 31, 126-133. [CrossRef]

2. Kelly, R.P.; Tunin, R.; Kass, D.A. Effect of reduced aortic compliance on cardiac efficiency and contractile function of in situ canine left ventricle. Circ. Res. 1992, 71, 490. [CrossRef] [PubMed]

3. Wayhs, R.; Zelinger, A.; Raggi, P. High coronary artery calcium scores pose an extremely elevated risk for hard events. J. Am. Coll. Cardiol. 2002, 39, 225-230. [CrossRef]

4. Keelan, P.C.; Bielak, L.F.; Ashai, K.; Jamjoum, L.S.; Denktas, A.E.; Rumberger, J.A.; Sheedy, I.I.P.F.; Peyser, P.A.; Schwartz, R.S. Long-term prognostic value of coronary calcification detected by electron-beam computed tomography in patients undergoing coronary angiography. Circulation 2001, 104, 412. [CrossRef] [PubMed]

5. Ohtsuka, S.; Kakihana, M.; Watanabe, H.; Sugishita, Y. Chronically decreased aortic distensibility causes deterioration of coronary perfusion during increased left ventricular contraction. J. Am. Coll. Cardiol. 1994, 24, 1406-1414. [CrossRef]

6. Yokoyama, M.; Origasa, H.; Matsuzaki, M.; Matsuzawa, Y.; Saito, Y.; Ishikawa, Y.; Oikawa, S.; Sasaki, J.; Hishida, H.; Itakura, H.; et al. Effects of eicosapentaenoic acid on major coronary events in hypercholesterolaemic patients (JELIS): A randomised open-label, blinded endpoint analysis. Lancet 2007, 369, 1090-1098. [CrossRef] 
7. Ishikawa, Y.; Yokoyama, M.; Saito, Y.; Matsuzaki, M.; Origasa, H.; Oikawa, S.; Sasaki, J.; Hishida, H.; Itakura, H.; Kita, T.; et al. Preventive effects of eicosapentaenoic acid on coronary artery disease in patients with peripheral artery disease. Circ. J. 2010, 74, 1451-1457. [CrossRef] [PubMed]

8. Doi, M.; Nosaka, K.; Miyoshi, T.; Iwamoto, M.; Kajiya, M.; Okawa, K.; Nakayama, R.; Takagi, W.; Takeda, K.; Hirohata, S.; et al. Early eicosapentaenoic acid treatment after percutaneous coronary intervention reduces acute inflammatory responses and ventricular arrhythmias in patients with acute myocardial infarction: A randomized, controlled study. Int. J. Cardiol. 2014, 176, 577-582. [CrossRef] [PubMed]

9. Nosaka, K.; Miyoshi, T.; Iwamoto, M.; Kajiya, M.; Okawa, K.; Tsukuda, S.; Yokohama, F.; Sogo, M.; Nishibe, T.; Matsuo, N.; et al. Early initiation of eicosapentaenoic acid and statin treatment is associated with better clinical outcomes than statin alone in patients with acute coronary syndromes: 1-Year outcomes of a randomized controlled study. Int. J. Cardiol. 2017, 228, 173-179. [CrossRef] [PubMed]

10. Kanai, S.; Uto, K.; Honda, K.; Hagiwara, N.; Oda, H. Eicosapentaenoic acid reduces warfarin-induced arterial calcification in rats. Atherosclerosis 2011, 215, 43-51. [CrossRef] [PubMed]

11. Wang, J.H.; Eguchi, K.; Matsumoto, S.; Fujiu, K.; Komuro, I.; Nagai, R.; Manabe, I. The $\omega-3$ polyunsaturated fatty acid, eicosapentaenoic acid, attenuates abdominal aortic aneurysm development via suppression of tissue remodeling. PLoS ONE 2014, 9, e96286. [CrossRef] [PubMed]

12. Nakamura, K.; Miura, D.; Saito, Y.; Yunoki, K.; Koyama, Y.; Satoh, M.; Kondo, M.; Osawa, K.; Hatipoglu, O.F.; Miyoshi, T.; et al. Eicosapentaenoic acid prevents arterial calcification in klotho mutant mice. PLoS ONE 2017, 12, e0181009. [CrossRef] [PubMed]

13. Polonsky, T.S.; McClelland, R.L.; Jorgensen, N.W.; Bild, D.E.; Burke, G.L.; Guerci, A.D.; Greenland, P. Coronary artery calcium score and risk classification for coronary heart disease prediction. JAMA 2010, 303, 1610-1616. [CrossRef] [PubMed]

14. Hoffmann, U.; Massaro, J.M.; D'Agostino, R.B., Sr.; Kathiresan, S.; Fox, C.S.; O’Donnell, C.J. Cardiovascular event prediction and risk reclassification by coronary, aortic, and valvular calcification in the framingham heart study. J. Am. Heart Assoc. 2016, 5. [CrossRef] [PubMed]

15. Lehmann, M.; Baarsma, H.A.; Konigshoff, M. Wnt signaling in lung aging and disease. Ann. Am. Thorac. Soc. 2016, 13, S411-S416. [CrossRef] [PubMed]

16. Yang, H.C.; Fogo, A.B. Fibrosis and renal aging. Kidney Int. 2014, 4, 75-78. [CrossRef] [PubMed]

17. Brack, A.S.; Conboy, M.J.; Roy, S.; Lee, M.; Kuo, C.J.; Keller, C.; Rando, T.A. Increased wnt signaling during aging alters muscle stem cell fate and increases fibrosis. Science 2007, 317, 807. [CrossRef] [PubMed]

18. Freise, C.; Kretzschmar, N.; Querfeld, U. Wnt signaling contributes to vascular calcification by induction of matrix metalloproteinases. BMC Cardiovasc. Disord. 2016, 16, 185. [CrossRef] [PubMed]

19. Shao, J.S.; Cheng, S.L.; Pingsterhaus, J.M.; Charlton-Kachigian, N.; Loewy, A.P.; Towler, D.A. Msx2 promotes cardiovascular calcification by activating paracrine wnt signals. J. Clin. Investig. 2005, 115, 1210-1220. [CrossRef] [PubMed]

20. Cai, T.; Sun, D.; Duan, Y.; Wen, P.; Dai, C.; Yang, J.; He, W. Wnt/beta-catenin signaling promotes VSMCS to osteogenic transdifferentiation and calcification through directly modulating Runx2 gene expression. Exp. Cell Res. 2016, 345, 206-217. [CrossRef] [PubMed]

21. Kuro-o, M.; Matsumura, Y.; Aizawa, H.; Kawaguchi, H.; Suga, T.; Utsugi, T.; Ohyama, Y.; Kurabayashi, M.; Kaname, T.; Kume, E.; et al. Mutation of the mouse klotho gene leads to a syndrome resembling ageing. Nature 1997, 390, 45-51. [CrossRef] [PubMed]

22. Liu, H.; Fergusson, M.M.; Castilho, R.M.; Liu, J.; Cao, L.; Chen, J.; Malide, D.; Rovira, I.I.; Schimel, D.; Kuo, C.J.; et al. Augmented Wnt signaling in a mammalian model of accelerated aging. Science 2007, 317, 803. [CrossRef] [PubMed]

23. Matsushita, K.; van der Velde, M.; Astor, B.C.; Woodward, M.; Levey, A.S.; de Jong, P.E.; Coresh, J.; Gansevoort, R.T. Association of estimated glomerular filtration rate and albuminuria with all-cause and cardiovascular mortality: A collaborative meta-analysis of general population cohorts. Lancet 2010, 375, 2073-2081. [PubMed]

24. Van der Velde, M.; Matsushita, K.; Coresh, J.; Astor, B.C.; Woodward, M.; Levey, A.; de Jong, P.; Gansevoort, R.T.; Chronic Kidney Disease Prognosis Consortium; van der Velde, M.; et al. Lower estimated glomerular filtration rate and higher albuminuria are associated with all-cause and cardiovascular mortality. A collaborative meta-analysis of high-risk population cohorts. Kidney Int. 2011, 79, 1341-1352. [PubMed] 
25. Hu, M.C.; Kuro-o, M.; Moe, O.W. Secreted klotho and chronic kidney disease. Adv. Exp. Med. Biol. 2012, 728, 126-157. [PubMed]

26. Zhou, L.; Li, Y.; Zhou, D.; Tan, R.J.; Liu, Y. Loss of klotho contributes to kidney injury by derepression of Wnt/Beta-catenin signaling. J. Am. Soc. Nephrol. 2013, 24, 771-785. [CrossRef] [PubMed]

27. Matsumura, Y.; Aizawa, H.; Shiraki-Iida, T.; Nagai, R.; Kuro-o, M.; Nabeshima, Y.-I. Identification of the human klotho gene and its two transcripts encoding membrane and secreted klotho protein. Biochem. Biophys. Res. Commun. 1998, 242, 626-630. [CrossRef] [PubMed]

28. Shiraki-Iida, T.; Aizawa, H.; Matsumura, Y.; Sekine, S.; Iida, A.; Anazawa, H.; Nagai, R.; Kuro-o, M.; Nabeshima, Y.-I. Structure of the mouse klotho gene and its two transcripts encoding membrane and secreted protein 1. FEBS Lett. 1998, 424, 6-10. [CrossRef]

29. Ritter, C.S.; Zhang, S.; Delmez, J.; Finch, J.L.; Slatopolsky, E. Differential expression and regulation of klotho by paricalcitol in the kidney, parathyroid, and aorta of uremic rats. Kidney Int. 2015, 87, 1141-1152. [CrossRef] [PubMed]

30. Mencke, R.; Harms, G.; Mirkovic, K.; Struik, J.; Van Ark, J.; Van Loon, E.; Verkaik, M.; De Borst, M.H.; Zeebregts, C.J.; Hoenderop, J.G.; et al. Membrane-bound klotho is not expressed endogenously in healthy or uraemic human vascular tissue. Cardiovasc. Res. 2015, 108, 220-231. [CrossRef] [PubMed]

31. Lindberg, K.; Olauson, H.; Amin, R.; Ponnusamy, A.; Goetz, R.; Taylor, R.F.; Mohammadi, M.; Canfield, A.; Kublickiene, K.; Larsson, T.E. Arterial klotho expression and FGF23 effects on vascular calcification and function. PLoS ONE 2013, 8, e60658. [CrossRef] [PubMed]

32. Kim, J.-S.; Crooks, H.; Dracheva, T.; Nishanian, T.G.; Singh, B.; Jen, J.; Waldman, T. Oncogenic $\beta$-catenin is required for bone morphogenetic protein 4 expression in human cancer cells. Cancer Res. 2002, 62, 2744. [PubMed]

33. Panizo, S.; Cardus, A.; Encinas, M.; Parisi, E.; Valcheva, P.; Lopez-Ongil, S.; Coll, B.; Fernandez, E.; Valdivielso, J.M. Rankl increases vascular smooth muscle cell calcification through a rank-bmp4-dependent pathway. Circ. Res. 2009, 104, 1041-1048. [CrossRef] [PubMed]

34. Lim, K.; Lu, T.S.; Molostvov, G.; Lee, C.; Lam, F.T.; Zehnder, D.; Hsiao, L.L. Vascular klotho deficiency potentiates the development of human artery calcification and mediates resistance to fibroblast growth factor 23. Circulation 2012, 125, 2243-2255. [CrossRef] [PubMed]

35. Voelkl, J.; Alesutan, I.; Leibrock, C.B.; Quintanilla-Martinez, L.; Kuhn, V.; Feger, M.; Mia, S.; Ahmed, M.S.; Rosenblatt, K.P.; Kuro, O.M.; et al. Spironolactone ameliorates pit1-dependent vascular osteoinduction in klotho-hypomorphic mice. J. Clin. Investig. 2013, 123, 812-822. [CrossRef] [PubMed]

36. Hasan, A.U.; Ohmori, K.; Konishi, K.; Igarashi, J.; Hashimoto, T.; Kamitori, K.; Yamaguchi, F.; Tsukamoto, I.; Uyama, T.; Ishihara, Y.; et al. Eicosapentaenoic acid upregulates VEGF-A through both GPR120 and PPAR $\gamma$ mediated pathways in 3T3-L1 adipocytes. Mol. Cell Endocrinol. 2015, 406, 10-18. [CrossRef] [PubMed]

37. Zhang, H.; Li, Y.; Fan, Y.; Wu, J.; Zhao, B.; Guan, Y.; Chien, S.; Wang, N. Klotho is a target gene of PPAR- $\gamma$. Kidney Int. 2008, 74, 732-739. [CrossRef] [PubMed]

38. Xu, H.E.; Lambert, M.H.; Montana, V.G.; Parks, D.J.; Blanchard, S.G.; Brown, P.J.; Sternbach, D.D.; Lehmann, J.M.; Wisely, G.B.; Willson, T.M.; et al. Molecular recognition of fatty acids by peroxisome proliferator-Activated receptors. Mol. Cell 1999, 3, 397-403. [CrossRef]

39. Moe, S.M.; Chen, N.X. Mechanisms of vascular calcification in chronic kidney disease. J. Am. Soc. Nephrol. 2008, 19, 213-216. [CrossRef] [PubMed]

40. De Montes Oca, A.; Guerrero, F.; Martinez-Moreno, J.M.; Madueno, J.A.; Herencia, C.; Peralta, A.; Almaden, Y.; Lopez, I.; Aguilera-Tejero, E.; Gundlach, K.; et al. Magnesium inhibits Wnt/beta-catenin activity and reverses the osteogenic transformation of vascular smooth muscle cells. PLoS ONE 2014, 9, e89525. [CrossRef] [PubMed]

41. Kageyama, A.; Matsui, H.; Ohta, M.; Sambuichi, K.; Kawano, H.; Notsu, T.; Imada, K.; Yokoyama, T.; Kurabayashi, M. Palmitic acid induces osteoblastic differentiation in vascular smooth muscle cells through ACSL3 and NF-kB, novel targets of eicosapentaenoic acid. PLoS ONE 2013, 8, e68197. [CrossRef] [PubMed]

42. Song, K.-S.; Jing, K.; Kim, J.-S.; Yun, E.-J.; Shin, S.; Seo, K.-S.; Park, J.-H.; Heo, J.-Y.; Kang, J.X.; Suh, K.-S.; et al. Omega-3-polyunsaturated fatty acids suppress pancreatic cancer cell growth in vitro and in vivo via downregulation of Wnt/Beta-catenin signaling. Pancreatology 2011, 11, 574-584. [CrossRef] [PubMed]

43. D'Eliseo, D.; Velotti, F. Omega-3 fatty acids and cancer cell cytotoxicity: Implications for multi-targeted cancer therapy. J. Clin. Med. 2016, 5, 15. [CrossRef] [PubMed] 
44. De Carlo, F.; Witte, T.R.; Hardman, W.E.; Claudio, P.P. Omega-3 eicosapentaenoic acid decreases CD133 colon cancer stem-like cell marker expression while increasing sensitivity to chemotherapy. PLoS ONE 2013, 8, e69760. [CrossRef] [PubMed]

45. Saremi, A.; Bahn, G.; Reaven, P.D.; VADT Investiqators. Progression of vascular calcification is increased with statin use in the Veterans Affairs Diabetes Trial (VADT). Diabetes Care 2012, 35, 2390-2392. [CrossRef] [PubMed]

46. Henein, M.; Granåsen, G.; Wiklund, U.; Schmermund, A.; Guerci, A.; Erbel, R.; Raggi, P. High dose and long-term statin therapy accelerate coronary artery calcification. Int. J. Cardiol. 2015, 184, 581-586. [CrossRef] [PubMed]

47. Nishio, R.; Shinke, T.; Otake, H.; Nakagawa, M.; Nagoshi, R.; Inoue, T.; Kozuki, A.; Hariki, H.; Osue, T.; Taniguchi, Y.; et al. Stabilizing effect of combined eicosapentaenoic acid and statin therapy on coronary thin-cap fibroatheroma. Atherosclerosis 2014, 234, 114-119. [CrossRef] [PubMed]

48. Niki, T.; Wakatsuki, T.; Yamaguchi, K.; Taketani, Y.; Oeduka, H.; Kusunose, K.; Ise, T.; Iwase, T.; Yamada, H.; Soeki, T.; et al. Effects of the addition of eicosapentaenoic acid to strong statin therapy on inflammatory cytokines and coronary plaque components assessed by integrated backscatter intravascular ultrasound. Circ. J. 2016, 80, 450-460. [CrossRef] [PubMed]

49. Honda, K.L.; Lamon-Fava, S.; Matthan, N.R.; Wu, D.; Lichtenstein, A.H. EPA and DHA exposure alters the inflammatory response but not the surface expression of Toll-like receptor 4 in macrophages. Lipids 2015, 50, 121-129. [CrossRef] [PubMed]

50. Wang, S.; Wu, D.; Lamon-Fava, S.; Matthan, N.R.; Honda, K.L.; Lichtenstein, A.H. In vitro fatty acid enrichment of macrophages alters inflammatory response and net cholesterol accumulation. Br. J. Nutr. 2009, 102, 497-501. [CrossRef] [PubMed]

51. Ishida, T.; Naoe, S.; Nakakuki, M.; Kawano, H.; Imada, K. Eicosapentaenoic acid prevents saturated fatty acid-induced vascular endothelial dysfunction: Involvement of long-chain acyl-Coa synthetase. J. Atheroscler. Thromb. 2015, 22, 1172-1185. [CrossRef] [PubMed]

52. Ma, B.; Hottiger, M.O. Crosstalk between Wnt/Beta-catenin and NF-kB signaling pathway during inflammation. Front. Immunol. 2016, 7, 378. [CrossRef] [PubMed]

53. Sumida, T.; Naito, A.T.; Nomura, S.; Nakagawa, A.; Higo, T.; Hashimoto, A.; Okada, K.; Sakai, T.; Ito, M.; Yamaguchi, T.; et al. Complement C1q-induced activation of beta-catenin signalling causes hypertensive arterial remodelling. Nat. Commun. 2015, 6, 6241. [CrossRef] [PubMed]

54. Matthijs Blankesteijn, W.; Hermans, K.C. Wnt signaling in atherosclerosis. Eur. J. Pharmacol. 2015, 763, 122-130. [CrossRef] [PubMed]

55. Dyall, S.C. Long-chain omega-3 fatty acids and the brain: A review of the independent and shared effects of EPA, DPA and DHA. Front. Aging Neurosci. 2015, 7, 52. [CrossRef] [PubMed]

56. Duvall, M.G.; Levy, B.D. DHA- and EPA-derived resolvins, protectins, and maresins in airway inflammation. Eur. J. Pharmacol. 2016, 785, 144-155. [CrossRef] [PubMed]

57. Oh, S.F.; Pillai, P.S.; Recchiuti, A.; Yang, R.; Serhan, C.N. Pro-resolving actions and stereoselective biosynthesis of $18 \mathrm{~S}$ E-series resolvins in human leukocytes and murine inflammation. J. Clin. Investig. 2011, 121, 569-581. [CrossRef] [PubMed]

58. Basil, M.C.; Levy, B.D. Specialized pro-resolving mediators: Endogenous regulators of infection and inflammation. Nat. Rev. Immunol. 2016, 16, 51-67. [CrossRef] [PubMed]

59. Romano, M.; Cianci, E.; Simiele, F.; Recchiuti, A. Lipoxins and aspirin-triggered lipoxins in resolution of inflammation. Eur. J. Pharmacol. 2015, 760, 49-63. [CrossRef] [PubMed]

(C) 2017 by the authors. Licensee MDPI, Basel, Switzerland. This article is an open access article distributed under the terms and conditions of the Creative Commons Attribution (CC BY) license (http:/ / creativecommons.org/licenses/by/4.0/). 